\title{
The value relevance of voluntary disclosure in the annual report
}

\author{
Banghøj, Jesper; Plenborg, Thomas
}

Document Version

Final published version

Publication date:

2006

\section{License \\ CC BY-NC-ND}

Citation for published version (APA):

Banghøj, J., \& Plenborg, T. (2006). The value relevance of voluntary disclosure in the annual report.

Link to publication in CBS Research Portal

\section{General rights}

Copyright and moral rights for the publications made accessible in the public portal are retained by the authors and/or other copyright owners and it is a condition of accessing publications that users recognise and abide by the legal requirements associated with these rights.

\section{Take down policy}

If you believe that this document breaches copyright please contact us (research.lib@cbs.dk) providing details, and we will remove access to the work immediately and investigate your claim. 
The value relevance of voluntary disclosure in the annual report

\author{
Assistant Professor Jesper Banghøj \\ Professor Thomas Plenborg \\ Copenhagen Business School \\ Department of Accounting and Auditing \\ Solbjerg Plads 3 \\ DK-2000 Frederiksberg \\ Denmark \\ Phone +4538152320 \\ Fax +45 38152321 \\ E-mail: \\ jb.acc@cbs.dk \\ tp.acc@cbs.dk
}

We gratefully acknowledge the helpful comments from Christian Petersen, Peter Ove Christensen, Bent Jesper Christensen, Frank Thinggaard, Johannes Raaballe and seminar participants at Aarhus University. 


\title{
The value relevance of voluntary disclosure in the annual report
}

\begin{abstract}
This paper examines if the level of voluntary disclosure affects the association between current returns and future earnings. Economic theory suggests that firms might find it advantageous to provide additional pieces of information (i.e., voluntary disclosure) to investors and analysts (Verrecchia 1983). Our results indicate that more voluntary disclosure does not improve the association between current returns and future earnings; i.e. current returns do not reflect more future earnings news. This finding raises the question whether voluntary information in the annual report contains value relevant information about future earnings or if investors are simply not capable of incorporating voluntary information in the firm value estimates.
\end{abstract}

Key words: Disclosure, future earnings, informativeness 


\section{The value relevance of voluntary disclosure in the annual report}

\section{Introduction}

This study examines whether a higher level of voluntary disclosure in the annual report reduces the information gap (asymmetry) between companies and investors in Denmark. A primary objective of disclosure is to inform analysts and investors about the amount, timing and uncertainty of future earnings (cash flows); i.e. disclosure helps analysts and investors to predict future earnings. Several studies document that a better disclosure practice improve analysts' forecast accuracy of next year's earnings (e.g. Lang and Lundholm, 1996). However, their results may simply reflect that firms manage their analyst relationship better. Thus, we take these results one step further by conjecturing that voluntary (disclosure) information in the annual report on future earnings is reflected in current stock prices. This implies that firms with a high level of (value relevant) voluntary disclosure have a stronger association between current stock returns and future earnings than firms with a low level of (value relevant) disclosure. Thus, our (alternative) hypothesis is that the level of voluntary disclosure improves the association between current stock returns and future earnings.

Only a few studies have addressed this problem. Lundholm and Myers (2002) and Gelb and Zarowin (2002) are notably exceptions. Based on US data both studies find that firms with relatively more informative disclosures 'bring the future forward' so that current stock returns reflect more future earnings news. However, Gelb and Zarowin (2002) also find that enhanced annual report disclosures do not make current stock prices more informative. This result seriously questions the usefulness of voluntary disclosure in the annual report. As no disclosure index is available in Denmark, it has been necessary to construct one on Danish firms. Our disclosure index purely relies on information from the annual report and our results are therefore comparable with the ones reported in Gelb and Zarowin (2002). 
Our study documents an increased level of disclosure across time. The level of voluntary disclosure, as measured in this study, increases by approximately 40 percent during the period 1996-2000. Our empirical results support the findings in Gelb and Zarowin (2002). Despite an increased level of voluntary disclosure we find that voluntary disclosure from the annual report does not improve the association between current stock returns and future earnings. In fact, in some of the alternative specifications we find that a higher level of voluntary disclosure in the annual report reduces the association between current returns and future earnings. While the objective of the annual report is to provide useful information to the stakeholders, investors in Danish companies have not benefited from an improved level of voluntary disclosure. This raises the question whether voluntary information in the annual report does not contain value relevant information about future performance or if investors are simply not capable of incorporating voluntary information in the firm value estimates.

The Copenhagen Stock Exchange is a small stock exchange with only 185 listed companies in 2004. In 2004 the OMXC20 index comprising the 20 blue chips stocks accounted for approximately 76\% of the total market value and $79 \%$ of total turnover (Copenhagen Stock Exchange, 2005). As such the CSE has the features of a typical continental European market. This supports that results from this study may be generalised to other settings than the US.

In her speech at the AAA meeting Schipper (2005) argues that investors underweight (or ignore altogether) disclosures. Hence, she points out that it is important to improve our understanding of how the market reads disclosure in the annual report. In a review of the empirical disclosure literature Healy and Palepu (2000) find that nearly all studies on disclosure are based on US data. They question whether the results from the US can be generalised to non-US countries characterised by a different institutional setting. For example, Hope (2002) finds that firms’ disclosure practices vary substantially across countries. This may imply that disclosure serves different purposes and that 
the value relevance of the disclosure, therefore, may vary substantially across countries. More specifically, does disclosure have the same effect on the association between current stock returns and future earnings? While both the US and Denmark are considered as developed countries there are several institutional differences that may affect the impact of voluntary disclosure on the association between current stock returns and future earnings.

Danish corporate ownership structure generally reflects an institutional setting that is similar to most non-US countries, where frequent heavily-concentrated shareholdings and controlling ownership are prevalent (Shleifer and Vishny, 1997, pp. 754-55). Pedersen and Thomsen (1996) document that the existence of dual stock classes in Denmark is related to a higher level of family ownership and shareholder concentration than in the US. Warfield et al. (1995) find that the mean percentage of shares owned by US managers is 17 percent, while Gabrielsen et al. (2002) find that the mean percentage of shares owned by Danish managers is as high as 59 percent. The existence of more heavily concentrated shareholdings and controlling ownership in Denmark may imply different reporting practices. For example, firms with high ownership concentration may be reluctant to provide voluntary disclosure since owners have alternative ways (inside) of getting information. Consequently, the market for voluntary disclosure may not be as developed in Denmark as in the US, which reduces the chances that voluntary disclosure is used as a mean to diminish the information asymmetry.

On the other hand, Warfield et al (1995) argue that because of greater ownership concentration, companies are more likely to disclose accounting information that reflects firm economics. Other research supports this position. Grossmann and Hart (1980) and Shleifer and Vishny (1986) find that in firms with many shareholders, it is not worthwhile for an individual investor to monitor management's performance. According to the monitoring 'theory' in a setting like the Danish with a high level of ownership concentration it is likely that voluntary disclosure is used as a mean to 
reduce the information asymmetry. Large shareholders will discipline the management to produce value relevant information that will reduce the information asymmetry.

The above considerations suggest that different ownership concentrations most likely will have an impact on firms' disclosure policy. However, it is not possible to predict a priori how the ownership concentration affects the relationship between the level of disclosure and the prediction of future earnings.

Expected litigation costs affect managers’ and auditors’ disclosure decisions (Kothari et al., 1988). The expected costs are a function of lawsuit probability, award size and legal fees. In countries with high litigation costs, the reliability of the disclosure may be emphasised above relevance (Baginski et al., 2002). In line with Ball et al. (2000) we expect that litigation costs in the US is relatively higher than in the UK and code-law countries. Litigation costs in Denmark are very similar to the UK. Thus, an emphasis on relevant disclosure at the expense of reliable disclosure may be relatively more likely in a less litigious environment as the Danish. If investors prefer information, which is relevant albeit less reliable, we expect to find support for our hypothesis, i.e. that the level voluntary disclosure reduces the information asymmetry and thereby improve the association between current stock returns and future earnings.

An American company must prepare a 10-K statement as requested by the Security and Exchange Commission (SEC). This statement gives investors a broad insight into a firm’s operations. Danish firms, on the other hand, are subject to a high degree of freedom when choosing how much information to disclose in the annual report. Hope (2002) also finds that the enforcement of accounting information varies substantially between the US and Denmark. He finds that the regulatory environment in the US is much more efficient than the regulatory environment in Denmark. As pointed out by Hope (2002), in the absent of adequate enforcement, even the best 
accounting standards will be inconsequential. The more detailed accounting regulation in the US combined with a better regulatory environment is likely to reduce information asymmetry. This study contributes to the literature by examining whether companies in a setting with a modest level of accounting regulation 'fill out the information gap' through voluntary disclosure and thereby improve investor protection. If Danish companies succeed in reducing the information gap (asymmetry) there are reasons to believe that the association between current stock returns and future earnings will improve.

Finally, with the implementation of the Danish Financial Accounting Act as of January 1, 2002 and the requirement that all listed companies in EU must comply with IAS standards from 2005 more openness in the annual accounts is required. Evidence from Danish listed companies may therefore shred new light on firms’ disclosure policy. If the level of voluntary disclosure reduces information asymmetry it may lead to better prediction of future earnings by investors after the implementation of IFRS standards in 2005.

The remaining of this paper is organized as follows. The next section contains a literature review. In the third section the research design is outlined. The sample selection and descriptive statistics are provided in the fourth section, followed by the empirical results and sensitivity checks. Conclusions and suggestions for future research appear in the final section.

\section{Relation to prior literature}

It is often argued that firms might find it advantageous to provide additional pieces of information (i.e., voluntary disclosure) to investors and analysts through the annual report. If a firm withhold information from the market, investors become suspicious about the quality of investment and discount its quality to the point where managers always are better off with a full disclosure policy (Verrecchia, 1983). On the other hand, Edwards and Smith (1996) find that one third of the 
participants in a survey believe that an increased level of disclosure leads to a loss of competitive advantage (disclosure costs). Hope (2002) also demonstrates that firms’ disclosure practices vary substantially across countries. Thus, the level of disclosure varies both across countries and companies.

Prior studies attempting to empirically assess the benefits of enhanced disclosure practices mainly focus on the benefits to the disclosing firm. For example, Botosan (1997) finds that firms that are not closely followed by financial analysts experience lower cost of capital with increases in disclosure. In a similar study Botosan and Plumlee (2002) create three disclosure indices based on information from the annual report, other publications and investor relations, respectively. They find contrary to expectations that the overall disclosure level is not associated with a lower cost of equity capital. Sengupta (1998) provides evidence that firms with high disclosure quality ratings from financial analysts enjoy lower costs of issuing debt. Based on German and Swiss data, respectively, Leuz and Verrecchia (2000) and Hail (2002) find a negative association between disclosure and various proxies for cost of capital. In the only study on disclosure in Denmark, Petersen and Plenborg (2006) find that voluntary disclosure is negatively associated with proxies for information asymmetry. ${ }^{1}$

Lang and Lundholm (1996) find that the level of analysts' disagreement (i.e. earnings forecast) to be driven by the quality of management disclosures. They argue that as firms disclose more value relevant information, analysts will rely more on the disclosed information in preparing their earnings forecast. Their empirical findings also show that enhanced disclosure practices is associated with more accurate analysts’ forecasts. In a European study Vanstraelen et al. (2003) find that the voluntary disclosure of forward-looking information is associated with significantly lower dispersion levels and higher accuracy of analysts’ earnings forecast. On the other hand, voluntary disclosure on historical information does not affect either the dispersion or accuracy of analysts’ 
earnings forecasts. Contrary to Lang and Lundholm and Vanstraelen et al. this study measures the association between current returns and future earnings directly, rather than relying on proxies such as analyst forecasts. As pointed out by Gelb and Zarowin (2002, 35), “more accurate analyst forecasts might be evidence of firms 'managing' their analyst relationships better (i.e. whisper numbers), rather than evidence that there are economically important and empirically detectable benefits of enhanced disclosure, which suggest that enhanced disclosure might make prices more informative”.

Only a few studies have examined if enhanced disclosure is associated with stock prices that are more informative about future earnings. Miller and Piotroski (2000) find that when firms include forward-looking statements in their quarterly earnings announcements, the announcement-period stock returns are more highly associated with the next quarter's earnings information. Lundholm and Myers (2002) find that firms with relatively more informative disclosures 'bring the future forward' so that current stock returns reflect more future earnings news. In a similar study, Gelb and Zarowin (2002) obtain a better association between current stock returns and future earnings for companies with better disclosure practices. Gelb and Zarowin (2002) also examine the usefulness of three disclosure indices. ${ }^{2}$ They find that enhanced annual report disclosures do not make current stock prices more informative. In summary, our literature review supports that a firm’s disclosure practice affects the association between current returns and future earnings. However, the disclosure from the annual report does not contain value relevant information about future earnings.

\section{Research design}

This section discusses the methodology adopted and the construction of the disclosure index. 


\section{Methodology}

Our approach to measuring current and future earnings news in current returns follows the work of Kothari and Sloan (1992), Collins et al. (1994), Lundholm and Myers (2002) and Gelb and Zarowin (2002). Based on the observation that accounting recognition lags stock returns in measuring value creation, these papers add future earnings into the regression of current returns on current earnings.

Collins et al. (1994) apply the following specification:

$R_{t}=\beta_{0}+\beta_{1} U X_{t}+\sum_{i=1}^{3} \beta_{i+1} \Delta E_{t}\left(X_{t+i}\right)+\varepsilon_{t}$

where

$\mathrm{R}_{\mathrm{t}} \quad=\quad$ Annual stock returns

$\mathrm{UX}=$ Unanticipated earnings

$\Delta \mathrm{E}(\mathrm{X})=$ Revision in market expectations from the beginning of period $\mathrm{t}$

Collins et al. limit $i$ to three years. They find that current returns do not significantly anticipate earnings changes more than three years ahead.

Since the independent variables are not directly observable we apply the level of $\mathrm{X}_{\mathrm{t}}$ and $\mathrm{X}_{\mathrm{t}-1}$ as proxy for UX. Thus, our specification becomes:

$R_{t}=\beta_{0}+\beta_{1} X_{t-1}+\beta_{2} X_{t}+\sum_{i=1}^{3} \beta_{3 i} X_{t+i}+\varepsilon_{t}^{3}$

As pointed out by Lundholm and Myers, by including $\mathrm{X}_{\mathrm{t}-1}$ we allow the regression to find the best representation of the prior expectation of current earnings. If the coefficient of $\mathrm{X}_{\mathrm{t}-1}$ is negative (but of similar magnitude) the earnings follow a random walk. If the coefficient on $\mathrm{X}_{\mathrm{t}-1}$ is zero then earnings is being treated as white noise. Consistent with prior literature we expect the coefficients on $\mathrm{X}_{\mathrm{t}}$ and $\mathrm{X}_{\mathrm{t}+\mathrm{i}}$ to be positive. 
Collins et al (1994) point out an error in variables problem. In the specification (2) we apply realised future earnings as proxy for expected future earnings, but realised earnings has both expected and unexpected components, so this proxy contains measurement error. Collins et al. (1994) include future stock returns in the regressions to control for the unexpected component of future earnings. In an efficient market, the unexpected components will be reflected in future stock returns.

Accordingly, we include future returns as a control variable.

$R_{t}=\beta_{0}+\beta_{1} X_{t-1}+\beta_{2} X_{t}+\sum_{i=1}^{3}\left(\beta_{3 i} X_{t+i}+\beta_{4 i} R_{t+i}\right)+\varepsilon_{t}$

In general, future returns should be uncorrelated with current returns in a regression excluding future earnings. Collins et al. (1994) find that the sign on future returns is negative and significant, which indicates that irrelevant components related to future returns are removed from future earnings, leaving a better approximation to the changes in expectations of future earnings that occurred in period $t$.

We assume that companies that disclose information about future earnings will improve the association between current returns and future earnings. On the other hand, companies that do not disclose information about future earnings will experience a weaker association between current returns and future earnings. Thus, there is an interaction between future earnings and the current level of a firm's disclosure which we incorporate in the regression as follows:

$$
\begin{aligned}
& R_{t}=\beta_{0}+\beta_{1} X_{t-1}+\beta_{2} X_{t} \\
& +\sum_{i=1}^{3}\left(\beta_{3 i} X_{t+i}+\beta_{4 i} R_{t+i}\right)+\beta_{5} D_{t}+\beta_{6} X_{t-1} \cdot D_{t}+\beta_{7} X_{t} \cdot D_{t}+\sum_{i=1}^{3}\left(\beta_{8 i} X_{t+i} \cdot D_{t}+\beta_{9 i} R_{t+i} \cdot D_{t}\right)+\varepsilon_{t}
\end{aligned}
$$


$\mathrm{D}$ is the disclosure score. We hypothesise that the association between current return and future earnings will improve for firms that disclose (current) information about future earnings; i.e. disclosures that reveal information about the future earnings potential will be incorporated in the current stock prices by investors. The coefficient on the interaction term $\mathrm{X}_{\mathrm{t}+\mathrm{i}} \cdot \mathrm{D}_{\mathrm{t}}$ is therefore expected to be positive. We don't have any prediction on the coefficient on the interaction term $R_{t+i} \cdot D_{t}$.

There are 17 variables in (4). In addition we add a number of control variables. Thus, in the interest of parsimony we apply a reduced version of (4):

$$
\begin{aligned}
& R_{t}=\beta_{0}+\beta_{1} X_{t-1}+\beta_{2} X_{t}+\beta_{3} X_{3}+\beta_{4} R_{3}+ \\
& \beta_{5} D_{t}+\beta_{6} X_{t-1} \cdot D_{t}+\beta_{7} X_{t} \cdot D_{t}+\beta_{8} X_{3} \cdot D_{t}+\beta_{9} R_{3} \cdot D_{t}+\varepsilon_{t}
\end{aligned}
$$

where

$\mathrm{R}_{3}=$ The buy and hold return for three years period following $t$. The buy and hold return is measured as 4 months after the fiscal year-end $t$ to 4 months after the fiscal year-end $t+3$.

$\mathrm{X}_{3}=$ The sum of annual earnings for three years following $t$, all deflated by the market value of equity four months after $\mathrm{t}-1$ fiscal year-end.

By aggregating three years of data we force each year to have the same coefficient. On the other hand, we reduce the number of independent variables from 17 to 9. Lundholm and Myers (2002) also adopt the approach and they obtain identical results with models (4) and (5). As sensitivity test we also run model (4) allowing the coefficients on future earnings and future returns to vary across time.

Previous studies have documented that the level of disclosure is correlated with ownership concentration, size and leverage. Petersen and Plenborg (2006) find a negative correlation between ownership concentration and a firm’s disclosure score. Neither Gelb and Zarowin (2002) nor 
Lundholm and Myers (2002) control for ownership concentration. Further, Lang and Lundholm (1993) find that firms with higher disclosure scores are larger than firms with lower scores. Ahmed and Courtis (1999) provide a meta analysis of 23 separate studies of the association between the disclosure level in the annual reports and various firm characteristics. They find that leverage is correlated with disclosure level. Thus, ownership concentration, size and leverage are included in (5) as control variables. In addition, Lundholm and Myers (2002) also include past growth, risk, and presence of accounting loss as control variables. To rule out that our disclosure score is merely a proxy for these determinants of the earnings response coefficient we also include them as additional control variables.

Leverage is defined as book value of equity scaled by total liabilities. Growth is measured as the percentage growth in total assets from period $t-1$ to $t$. Loss is an indicator variable that equals 1 when earnings is negative and zero otherwise. Beta (risk) is estimated via a market model regression using at least 24 of the 60 monthly return observations for the year in question (e.g., 1996) and the preceding four years. The accounting variables (i.e. earnings, book value of equity, total liabilities, and total assets) and monthly stock returns (prices) are retrieved from Datastream. ${ }^{4}$ Size (MV) is measured as the log of market value of a firm’s equity. Ownership concentration (Owner) is measured as shares held by blockholders including officers, directors (and their families), trusts, pension/benefit plans, and shares held by other firms or individuals that hold more than $5 \%$. The data is obtained from Worldscope International Database, Greens and annual reports. ${ }^{5}$ Since Danish ownership data are both difficult and extremely time consuming to collect we use ownership data for 1998 as proxy for the entire period, 1996-2000. A similar assumption is introduced in previous ownership studies such as Warfield et al. (1995) on US data and Gabrielsen (2002) on Danish data. 


\section{Construction of the disclosure index}

Most prior studies on disclosure used data from the Association of Investment Management and Research (AIMR) as a proxy for firms’ disclosure policy. Every year AIMR publishes a disclosure index for almost 500 firms comprising 22 different industries based on a number of financial analysts assessment of the selected industries disclosure policy. Only a few studies (e.g., Botosan, 1997) created their own disclosure index. As no disclosure index that resembles the one by AIMR is available in Denmark, it has been necessary to construct a similar one on Danish firms. The design of the index is inspired by earlier studies and reports as for example, Jenkins (1994), Botosan (1997), PwC ValueReporting (1999) and the Nørby (2001) ${ }^{6}$ Common to these studies is the focus on investors' need. Our disclosure index purely relies on information from the annual report and is based on the following five subcategories: 1) Strategy, 2) Competition and outlook, 3) Production, 4) Sales and marketing, and 5) Human capital. ${ }^{7}$

A total of 62 indicators within the five groups have been identified (see exhibit A). The Financial Statement Act does not require disclosure of any of those indicators. Thus, disclosing any of the 62 indicators is entirely voluntary. ${ }^{8}$ Even though the 'level of disclosure' is measured by the number of indicators (i.e., quantitative measure), they should also be qualitative in order to be informative. As our index is based on prior research and reports, it provides some evidence, albeit indirectly, that the indicators are qualitative as well.

By assigning points for each of the 62 information indicators a firm disclose, each firm gets a score on the disclosure index. Since one point is assigned for each piece of information in the annual report the maximum score is 62. This scoring procedure differs from the one that Botosan (1997) uses, as she awards each quantitative measure a score of two and each qualitative measure a score of one. She argues that quantitative measures are more precise than qualitative measures. Even though quantitative measures may be more precise, that is, more reliable, qualitative measures may be more 
relevant. Arguably, qualitative information may in some cases provide investors with a better understanding of firm characteristics that determines the future earnings potential. Consequently, this study assigns an equal score to each of the two measures. Finally, only one point is given for each piece of information even if this piece of information appears more than once in the annual report.

\section{Sample selection and descriptive statistics}

\section{Sample selection}

This study includes 36 industrial firms listed on the Copenhagen Stock Exchange. We use the annual reports for the period 1996 - 2000 to construct the disclosure score. ${ }^{9}$ The reports were carefully examined, and the relevant pieces of voluntary disclosure were extracted for each of the five disclosure indices. The final sample of 36 firms was selected as follows. In order to obtain variety in disclosure level a large sample is preferable. However, we focus on only one industry to control for other factors besides disclosure that affect the relation between current returns and future earnings. Since firms in an industry are homogeneous in their real activities and most likely adopt similar accounting practice (White et al. 2003) their earnings should have similar timeliness and forecast ability. The Copenhagen Stock Exchange industrial index consists of 58 firms, and was chosen since it is the largest index (i.e., the one including the largest number of firms). Within this group the subgroup 2010 Industrial goods has been selected comprising 45 firms. Thus, 13 firms in the subgroups ‘Commercial Service Suppliers’ and ‘Transportation’ were deselected as those firms differ from the majority of other industrial firms as they do not have any physical production line. Finally, a total of nine firms were eliminated to avoid double counting, as those nine firms are represented in the industrial index by two stock classes. The final sample consists of 36 firms covering the period 1996 - 2000 totalling 152 firm-year observations. ${ }^{10}$ 


\section{Descriptive statistics}

Table 1 provides summary statistics for our sample. The mean (median) current return is $7.3 \%$ (2.4\%). The mean (median) current earnings (deflated by market value) is $11.1 \%$ (9.9\%). The mean (median) accumulated three year earnings is as expected roughly three times the size of current earnings. On the other hand, future returns is negative which may indicate structural changes in the returns over sample time. A closer look at the returns reveals that differences in measurement periods explain the differences between current and future returns. Current returns are measured in the time period 1996-2000 while future returns are measured in the time period 1997-2003. For example, future returns are not affected by the strong (current) returns of 32\% in 1996. Further, future returns are affected by poor (negative) stock market performance in 2001 and 2002. The negative value on future returns may affect the measure's ability to proxy for measurement error in future earnings (the unexpected component of future earnings). ${ }^{11}$

\section{(INSERT TABLE 1 ABOUT HERE)}

Our sample consists of companies that are slightly bigger than the average company on the stock exchange. While the median market value of equity for companies listed at the stock exchange is 972 mio. DKK in the time period examined the median market value of equity for companies included in our sample is 1,165 mio. DKK.

As evidenced by table $1 \mathrm{~b}$ the mean (median) disclosure score is increasing over time from 9.9 (11.0) in 1996 to 14.6 (14.0) in 2000. This trend is the same for all five subcategories. The score for strategy, competition and production is significantly higher than for marketing strategy and human resource. For 2000 the score on strategy was the highest score, suggesting that management find information about strategy an important issue. Even though the firms of today are increasingly 
dependent upon intangible resources at large, including know-how and skills of employees, disclosure on human capital (HR) is still fairly low. ${ }^{12}$

\section{(INSERT TABLE 2 ABOUT HERE)}

Table 2 provides correlations between the dependent and independent variables. As documented in previous studies current returns (R) are strongly correlated with both current (X) and future earnings (X3). Further, current returns are uncorrelated with future returns (R3). Future returns, on the other hand, are significantly correlated with future earnings (X3), consistent with Collins et al. (1994). These correlations indicate that future returns should not influence the results except through their role as a proxy for the measurement error in future earnings.

The coefficient on the correlation between current returns and the disclosure score is only $5 \%$ and insignificant. This indicates that the disclosure practice in Danish companies is not necessarily driven by current performance. Lundholm and Myers (2002) find a positive and significant correlation between current returns and the disclosure score. However, their correlation coefficient is only $3 \%$ which indicates that the significance level is affected by the sample size $(n=4,478)$. Size measured as the market value of equity is correlated with disclosure. Thus, larger companies seem to have a more rigorous information policy. This is consistent with the results reported in Lang and Lundholm (1993). They find that firms with higher disclosure scores are larger than companies with lower scores. The correlations between the independent variables are in general modest and multicollinearity does not seem be an issue.

\section{Empirical results}

In the spirit of Lundholm and Myers (2002) we report the results based on specification 5 above. In a specification (model 1) similar to Collins et al. (1994) we find that the coefficient on current 
earnings is positive and significant at the $1 \%$ level. ${ }^{13}$ Further, current returns contain information about future earnings. The coefficient on X3 is both positive and significant at the $1 \%$ level. This is consistent with accounting recognition lags stock returns in measuring value creation. The coefficient on R3 is negative and significant at the $1 \%$ level indicating that realised future earnings contains measurement error that future returns removes. The coefficient on $\mathrm{X}_{\mathrm{t}-1}$ is negative but insignificant. The negative sign on $\mathrm{X}_{\mathrm{t}-1}$ suggests that earnings follow a random walk. Thus, based on Danish data we obtain results that are similar to the ones in Collins et al. (1994).

\section{(INSERT TABLE 3 ABOUT HERE)}

In model 2 we include the disclosure score. In general, the results remain similar to the ones reported in model 1 . The coefficient on X3 is still positive and significant which suggests that current returns contain information about future earnings. However, the coefficients on DS and the interaction term of DS and X3 are not significantly different from zero. Since DS*X3 and DS*R3 together proxy for realised future earnings a more powerful test examines the joint significance of DS*X3 and DS*R3. The partial F-test of the joint test of these variables is 0.10 and insignificant. These results reject the basic idea that disclosures publish in the annual report reveal information about future earnings.

In table 3 we apply a model where three years of accumulated earnings is included. However, by aggregating three years of earnings we are essentially restricting the coefficient on earnings to be similar for each firm year. We therefore run a regression where each year of future earnings and future returns are included in the regression separately. The results are reported in table 4.

(INSERT TABLE 4 ABOUT HERE) 
While the sign of the coefficients on $\mathrm{X}_{\mathrm{t}-1}$ and $\mathrm{X}_{\mathrm{t}}$ have the expected sign they are not significantly different from zero. Only the coefficient on $\mathrm{X}_{\mathrm{t}+1}$ is positive and significantly different from zero (10\% level). This indicates that our result in table 3 is primarily driven by next year's earnings. Current returns do not contain information about earnings two or three years ahead. This result contradicts the findings in Collins et al. (1994) and suggests that current returns in Denmark is less informative about future earnings than current returns in the US. More importantly, the coefficient on DS remains close to zero. The coefficient on the interaction terms, DS* $\mathrm{X}_{\mathrm{t}+\mathrm{i}}$ and $\mathrm{DS} * \mathrm{R}_{\mathrm{t}+\mathrm{i}}$, are in general not significantly different from zero. A notably exception is the coefficient on DS* $\mathrm{X}_{2}$ which is positive and significant at the $10 \%$ level. ${ }^{14}$ As pointed out above, DS*X3 and DS*R3 together proxy for realised future earnings. Consequently, we examine the joint significance of DS* $\mathrm{X}_{\mathrm{t}+\mathrm{i}}$ and DS* $R_{t+i}$. The partial F-test of the joint test of these variables is 0.71 and insignificant which reinforces that voluntary disclosure from the annual report does not bring future earnings forward in time.

We also included yearly indicator variables in the regressions. ${ }^{15}$ The resulting coefficient estimates are consistent with the ones reported in table 3 and the significance levels remain unchanged (not tabulated). ${ }^{16}$

In order to examine if some of the information in the disclosure contain value relevant information we decompose our disclosure index according to the five categories (strategy, competition and outlook, production, sales and marketing, and human capital) and run a regression for each subdisclosure index. However, the coefficients on the disclosure index and interaction terms are not significantly different from zero (not reported).

(INSERT TABLE 5 ABOUT HERE) 
We also run regressions including the following control variables: leverage, growth, loss indicator, risk, size and ownership. ${ }^{17}{ }^{18}$ The results are reported in table 5. The results remain qualitatively similar to the ones reported in the table 3. For example, the coefficients on DS*X3 and DS*R3 remain consistently close to zero and insignificant.

While our earnings metric is ordinary earnings Gelb and Zarowin (2002) apply Earnings Before Interest, Tax, Depreciation, and Amortisation (EBITDA). As a sensitivity check we replace ordinary earnings with EBITDA. However, the results (not tabulated) do not seem be affected by the choice of earnings measure.

Collins et al. (1994) and Gelb and Zarowin (2002) apply changes in future earnings rather than a level specification. ${ }^{19}$ Assuming earnings follow a random walk process earnings change is a more appropriate specification. We therefore replicate our tests above using earnings change. The results (not reported) remain almost identical to the ones based on our level specification. Thus, voluntary disclosure does not improve the informativeness of current returns.

As a sensitivity check we replace future returns with growth in investments as a proxy for the measurement error in future earnings consistent with Collins et al. 1994. However, the results (not reported) remain unchanged.

An explanation for the lack of value relevance of voluntary disclosure may be that many companies have a similar reporting practice. Thus, to improve the variation in the disclosure score we examine a sub sample including only the companies appearing in the top/bottom quartile of the disclosure index. Following this procedure isolate the most/least informative firms but also reduce the sample size. The results are reported in table 6. 
(INSERT TABLE 6 ABOUT HERE)

While the coefficient on current earnings is close to zero the coefficient on future earnings is positive and significant at the $1 \%$ level. Further, the coefficient on DS is positive and significant at the $10 \%$ level. On the other hand, the coefficient on the interaction term is negative which indicates that a higher level of voluntary disclosure reduces the association between current returns and future earnings. This works against our hypothesis that voluntary disclosure informs investors about the amount, timing and uncertainty of future earnings. As can be seen from table 6 this result remains robust across most alternative specifications. The coefficient on the interaction term becomes insignificant only when financial leverage and beta are included in the regression. The negative coefficient on the interaction between disclosure and future earnings is puzzling given the objective of the disclosure in the annual report.

As a last sensitivity test we also examine if companies that improve the level of voluntary disclosure across time experience a better association between current returns and future earnings. Specifically, we compare the coefficient on the interaction term between the disclosure score and future earnings before and after the improved disclosure score. Based on various specifications we are not able to detect any material difference in the coefficient on the interaction term (not reported). Thus, this result reinforces that voluntary disclosure does not improved the association between current returns and future earnings.

\section{Conclusion and future research}

This paper documents industrial firms' level of disclosure on 62 voluntary issues in the annual report which seem important to investors and financial analysts. Across time there is an increase in the level of voluntary disclosure. An examination of the impact of voluntary disclosure on the association between current returns and future earnings in a setting with high ownership 
concentration, low litigation costs, low enforcement of accounting information and a flexible accounting regime, yields results similar to the ones based on US data which is characterised by a different institutional setting. While Lundholm and Myers (2002) and Gelb and Zarowin (2002) find that voluntary disclosure affects the association between current returns and future earnings positively, Gelb and Zarowin also find that information from the annual report does not affect the relationship positively. These results raise the question whether voluntary information in the annual report does contain value relevant information about future performance or if investors are simply not capable of incorporating voluntary information in the firm value estimates.

The low and in some cases even negative coefficient on the interaction between disclosure and future earnings is puzzling given the objective of the disclosure in the annual report. One explanation is that the voluntary disclosure misleads analysts' perception of a company's future earnings potential, i.e. voluntary disclosure does not contain value relevant information about future earnings. Another explanation is that investors may simply not be capable of incorporating voluntary information in the firm value estimates. Finally, our disclosure index may contain a measurement bias. For example, some pieces of information may provide investors with a better understanding of firm characteristics that determines the future earnings potential. By assigning one point for each piece of (voluntary) information in the annual report we may introduce a measurement error in our disclosure index. However, Petersen and Plenborg (2006) apply the same disclosure index and find a negative and statistical significant association between the level of disclosure and proxies for information asymmetry (bid-ask spread and turnover ratio). Thus, voluntary disclosure seems to reduce the level of information asymmetry. Our results, however, show that voluntary disclosure does not also make current returns more informative about future earnings.

Our results are of interest to accounting standard setters. While the objective of the disclosure is to improve the predictability of future earnings our results (and the results of Gelb and Zarowin) show 
that voluntary information in the annual report in Denmark (and in the US) does not improve investors’ ability to predict future earnings.

Examining the impact of voluntary disclosure on the informativeness of current returns has other future avenues. For instance, an analysis (e.g. interviews) that explores how investors apply voluntary information may provide insights as to why voluntary information seems value irrelevant. Further, future studies may distinct between disclosure that provides information about good and bad earnings news, respectively. Basu (1997) has shown that bad earnings news are more timely than good earnings news. Thus, one may conjecture that the association between current returns and future earnings improves for companies that disclose relatively more good (earnings) news. Finally, the analyses and results reported in our paper are based on one industry for a five-year period. Thus, the results may not be generalizable to other industries, time periods and/or capital markets. These issues could be addressed in future research. 
${ }^{1}$ A review of the European Accounting Review, Journal of Business, Finance and Accounting, Accounting and Business Research and British Accounting Review over the past eight years (1998-2005) reveals that empirical studies on disclosure are rare.

${ }^{2}$ Both Lundholm and Myers (2002) and Gelb and Zarowin (2002) apply the AIMR-FAF disclosure scores. This disclosure is based on analyst rank of firms by the informativeness of their disclosures. Scores are given for the following three disclosure categories: Annual report, investor relations, and other publications.

${ }^{3}$ Gelb and Zarowin (2002) apply an alternative specification: $R_{t}=\beta_{0}+\beta_{1} \Delta X_{t}+\sum_{i=1}^{3} \beta_{2 i} \Delta X_{t+i}+\varepsilon_{t}$. We also apply the change specification of earnings. However, as shown in the empirical section we obtain results similar to the ones applying a level specification.

${ }^{4}$ To ensure the data quality we compared data from Datastream with data from the annual reports. We found that the data from Datastream are realiable; i.e. that data from Datastream correspond with data from the annual reports.

${ }^{5}$ In Denmark, investors owning 5 percent or more of a corporation's stock must report their holdings to the firm, and this information is then published with the company's annual report. In spite of this requirement, the exact voting power by an investor is not necessarily known because of the frequent occurrence of dual stock classes. Shares of different stock classes normally have different voting rights, but shareholders are not required to report the number of votes attached to their holdings. In eight cases it was necessary to approach the company for more detailed information about the voting power.

${ }^{6}$ The Nørby report contains recommendations about proper corporate governance. The Copenhagen Stock Exchange suggests that firms implement the recommendations from the Nørby committee.

${ }^{7}$ See Botosan (1997:327) for a discussion of advantages and disadvantages of using the AIRM disclosure index versus a self constructed disclosure index.

${ }^{8}$ Except in the rare case that the information is needed in order to give 'a true and fair view'.

${ }^{9}$ In order to be able to estimate future earnings 2000 was chosen as the last year. In fact, 2001 could have been used as the last year but at the time of the data collection we intended to apply four years of future earnings.

${ }^{10}$ The final sample size is also affected by missing observations and delistings/listings.

${ }^{11}$ As a sensitivity check we replace future returns with growth in investments as a proxy for the measurement error in future earnings. This is consistent with Collins et al. 1994 who also apply growth in investments as a proxy for the measurement error in future earnings.

${ }^{12}$ The modest focus on HR may simply reflect the nature of industry included in the analysis.

${ }^{13}$ All statistics are reported as two-tailed tests.

${ }^{14}$ The coefficient on X2 remains still negative for 'high' disclosure firms $(-0.74287+0.07536)$.

${ }^{15}$ We do not run year-by-year regressions because in some of the sample years, we have only about 26 observations, and the models examined estimate up to 21 parameters.

${ }^{16}$ Sensitivity checks that are not reported in tables are available upon request from the authors.

${ }^{17}$ Due to limited number of observations (degree of freedom) only one control variable is included in the model at a time. This corresponds to Lundholm and Myers (2002).

${ }^{18}$ By including control variables we expect to reduce the residuals although they will also affect our degree of freedom.

${ }^{19}$ Please note that the level specification adopted in this study is equivalent to using the level of past earnings and the change in current and future earnings. 


\section{References}

Ahmed, K., and Courtis, J. K. (1999). “Associations between corporate characteristics and disclosure levels in annual reports: A meta-analysis”, The British Accounting Review, 31(1), 35-61

Baginski, S.P., Hassell, J.M., and Kimbrough, M.D. (2002). “The effect of legal environment on voluntary disclosure: evidence from management earnings forecasts issued in the U.S. and Canadian markets”, The Accounting Review, Vol. 77, No. 1, pp. 25-50.

Ball, R., Kothari, S. P., and Robin, A. (2000). "The effect of international institutional factors on properties of accounting earnings”, Journal of Accounting and Economics, 29, 1-51.

Basu. S. (1997). “The conservatism principle and the asymmetric timeliness of earnings”, Journal of Accounting and Economics, 24, 3-28.

Botosan, C.A. (1997). "Disclosure level and the cost of equity capital”, The Accounting Review, 72(3), 323-49.

Botosan, C.A., and Plumlee, M.A. (2002). “A Re-examination of disclosure level and expected cost of equity capital”, Journal of Accounting Research, 40 (1), 2-40.

Collins, D.W., Kothari, S.P., Shanken, J., and R.G. Sloan (1994). “The lack of timeliness and noise as explanations for the low contemporaneous returns-earnings association”, Journal of Accounting and Economics, November, pp. 289-324.

The Copenhagen Stock Exchange (2005). Fact Book 2005 (Statistics 2004) - Fakta om Københavns Fondsbørs, Copenhagen.

Edwards, P. and Smith, R.A. (1996). "Competitive disadvantage and voluntary disclosures: The case of segmental reporting”, British Accounting Review, 28, pp. 155-172. 
Gabrielsen, G., Gramlich J., and Plenborg, T. (2002). “Managerial ownership, information content of earnings, and discretionary accruals in a non-US setting”, Journal of Business Finance and Accounting, 29(7\&8), 967-988.

Gelb. D.S. and Zarowin, P. (2002). “Corporate disclosure policy and the informativeness of stock prices”, Review of Accounting Studies, 7, pp. 33-52.

Grossman, S. J., and Hart, O. D. (1980). "Takeover bids, the free-rider problem, and the theory of the corporations”, Bell Journal of Economics, 11 (Spring), 42-64.

Hail, L. (2002). "The impact of voluntary corporate disclosure on the ex-ante cost of capital for Swiss Firms”, The European Accounting Review, 11(4), 741-773

Healy, P., and Palepu, K. G. (2000). “A review of the empirical disclosure literature”, Working paper, Harvard Business School.

Hope, O. K. (2002). “Disclosure practices, enforcement of accounting standards and analysts' forecast accuracy: An international study”, Working Paper, University of Toronto.

Jenkins Report (1994). Improving business reporting - A customer focus: Meeting the information needs of investors and creditors, American Institute of Certified Public Accountants, New York.

Kothari, S. P., Lys, T., Smith, C. W., and Watts, R. L. (1988). “Auditor Liability and Information Disclosure”, Journal of Accounting, Auditing and Finance 4(3), 307-367.

Kothari, S. P and Sloan, R. (1992). "Information in prices about future earnings: Implications for earnings response coefficients”, Journal of Accounting and Economics, 15, pp. 143-171.

Lang, M., and Lundholm, R. (1993). “Cross-sectional Determinants of Analyst Ratings of Corporate Disclosures”, Journal of Accounting Research, 31(2), 246-271. 
Lang, M., and Lundholm, R. (1996). “Corporate disclosure policy and analyst behavior”, The Accounting Review, 71(4), 467-492.

Leuz, C., and Verrecchia, R.E. (2000). “The economic consequences of increased disclosure”, Journal of Accounting Research, 38(Supplement), 91-124.

Lundholm, R. and.Myers, P. (2002). "Bringing the future forward: The effect of disclosure on the returns-earnings relation”, Journal of Accounting Research, Vol. 40, No. 3, June, pp. 809-839.

Miller, G.S. and Piotroski, J.D. (2000), “The role of disclosure for high book-to-market firms”, Working Paper, Harvard Business School.

Nørby, L. (2001). Corporate Governance i Danmark: Anbefalinger for god selskabsledelse i Danmark.

Pedersen, T., and Thomsen, S. (1996). “European patterns of corporate ownership: A twelvecountry study”, Journal of International Business Studies, 28, 759-778.

Petersen, C. and Plenborg, T. (2006). "Voluntary disclosure and information asymmetry in Denmark”, Journal of International Accounting, Auditing and Taxation, forthcoming (Summer).

PwC (1999). ValueReporting - Forecast 2000, PricewaterhouseCoopers.

Schipper, K. (2005). “Required disclosures in financial report”, Presentation at the American Accounting Association meeting in August, 2005.

Sengupta, P. (1998). "Corporate disclosure quality and the cost of debt”, Accounting Review, 73(4), 459-474.

Shleifer, A., and Vishny, R. (1986). "Large shareholders and corporate control”, Journal of Political Economy, 94(3), 461-488. 
Shleifer, A., and Vishny, R. W. (1997). “A survey of corporate governance”, Journal of Finance, 52, 737-783.

Vanstraelen, A., Zarzeski, M. T., and Robb, S.W.G. (2003). “Corporate nonfinancial disclosure practices and financial analyst forecast ability across three European countries”, Journal of international Financial Management and Accounting, 14:3, pp. 249-278.

Verrecchia, R. (1983). “Discretionary disclosure”, Journal of Accounting and Economics, 5, December, pp. 179-194.

Warfield, T. D., Wild, J. J., and Wild, K. L. (1995). “Managerial ownership accounting choices, and informativeness of earnings”, Journal of Accounting and Economics, 20, 61-91.

White, G.I., Sondhi, A.C., and Fried, D. (2003) “The analysis and use of financial statements”, Wiley, $3^{\text {rd }}$ edition. 


\section{Appendix A}

Strategy

A statement of corporate goals or objectives is provided?

A general statement of corporate strategy is provided?

Actions taken to achieve the corporate goal are discussed?

A time frame for achieving corporate goals is provided?

Attitude towards ethic questions is provided

Strategy towards environmental issues is provided?

Detailed segment performance is provided?*

Changes in ROCE or EVA are provided?

Commercial risk assessments are provided?

Financial risk assessments are provided?

Interest or exchange risks are discussed?

Other risk assessments are discussed?

\section{Competition and outlook}

The principal markets are identified?

Specific characteristics of these markets are described?

The market sizes are estimated?

Market share are provided?

The competitive landscapes are discussed?

Barriers to entry are discussed?

The market growths are estimated?

Change in market shares is discussed?

Impact of barriers to entry on profits is discussed?

The impact of competition on profits is discussed?

A forecast of market share is estimated?

Impact of barriers to entry on future profits is discussed?

The impact of competition on future profits is discussed?

\section{Marketing strategy}

Marketing strategy is provided?

Sales strategy is described?

Distribution channels are described?

Sales and marketing costs are provided

Brand equity/visibility ratings are discussed?

Customer turnover rates are discussed?

Customer satisfaction level is discussed?

Customer mix is discussed?

Revenues from new products/services are discussed?

Order backlog is provided?

Percent of order backlog to be shipped next year is provided?

Amount of new orders placed this year is provided?

Change in inventory is discussed?

\section{Human Capital}

Experience of management team is discussed?

Description of workforce is provided?

Amount spent on education is provided?

Employee retention rates are provided?

Average revenue per employee is provided?

Average age of key employees is provided?

Age of key employees is provided?

Other Measurement of intellectual capital is provided?

Investment in ERP is provided?

Strategy for measurement of human capital is discussed?

Strategy regarding ERP system is discussed?

\section{Production}

A general description of the business is provided?

The principal products/services are identified?

Specific char. of these products/services are described?

Speed to market is discussed?

$\mathrm{R} \& \mathrm{D}$ expenditures are discussed?

Investments in production are discussed?

Product development cycle is discussed?

Ratio of inputs to outputs is discussed?

New products are discussed?

Rejection/defect rates are discussed?

Volume of materials consumed is discussed?

Changes in production methods are discussed?

Changes in product materials are discussed? 
TABLE 1A

Descriptive Statistics (152 observations)

\begin{tabular}{|c|c|c|c|c|c|c|}
\hline Variable & Mean & Min & $25 \%$ & $50 \%$ & $75 \%$ & Max \\
\hline Current returns & 0.072559 & -0.65584 & -0.16652 & 0.02425 & 0.225362 & 1.365854 \\
\hline Current earnings & 0.110929 & -0.87639 & 0.061137 & 0.0993 & 0.17185 & 0.815636 \\
\hline 3 Year accumulated earnings & 0.245348 & -1.73423 & 0.050593 & 0.249902 & 0.422644 & 2.168396 \\
\hline 3 year accumulated buy and hold return & -0.07303 & -0.93301 & -0.40753 & -0.16935 & 0.276606 & 1.640964 \\
\hline Market value & 1165.034 & 19.08 & 106.15 & 275.13 & 868.905 & 45055.79 \\
\hline Disclosure score & 12.17763 & 0 & 7 & 12 & 17 & 30 \\
\hline
\end{tabular}

Current returns (Rt) for year $\mathrm{t}$ are the buy and hold returns for the 12 month period starting four months after year

t-1 fiscal year end. Current earnings (Xt) for the year $\mathrm{t}$ is ordinary income, scaled by market value at fiscal year end

Future earnings (X3t) is the sum of ordinary income for the three years following the current year scaled by market value at fiscal year end. Future returns (R3t) are the buy and hold returns for the three year period following the current year. Market value is the market value of equity at the fiscal yearend. DS is the disclosure score. 
Table $1 b$

Five types of disclosure scores from 1996-2000

\begin{tabular}{|c|c|c|c|c|c|c|c|c|c|c|c|c|c|}
\hline \multirow{3}{*}{1996} & \multirow{3}{*}{$\begin{array}{c}\mathrm{n}^{\mathrm{b}} \\
26\end{array}$} & \multicolumn{2}{|c|}{ DS } & \multicolumn{2}{|c|}{ STRA $^{\mathrm{a}}$} & \multicolumn{2}{|c|}{ COMP } & \multicolumn{2}{|c|}{ PROD } & \multicolumn{2}{|c|}{ MARK } & \multicolumn{2}{|c|}{ HR } \\
\hline & & Mean & Median & Mean & Median & Mean & Median & Mean & Median & Mean & Median & Mean & Median \\
\hline & & 9,9 & 11.0 & 2.6 & 2.0 & 2.7 & 2.0 & 3.4 & 3.0 & 0.8 & 1.0 & 0.4 & 0.0 \\
\hline 1997 & 31 & 10.3 & 11.0 & 2.8 & 3.0 & 2.6 & 2.0 & 3.5 & 3.0 & 0.8 & 1.0 & 0.6 & 0.0 \\
\hline 1998 & 34 & 12.5 & 12.5 & 3.7 & 4.0 & 2.9 & 2.5 & 3.6 & 3.0 & 0.9 & 0.5 & 1.4 & 1.0 \\
\hline 1999 & 32 & 13.3 & 12.5 & 4.0 & 4.0 & 2.9 & 3.0 & 3.9 & 4.0 & 1.1 & 0.5 & 1.3 & 1.0 \\
\hline 2000 & 29 & 14.6 & 14.0 & 4.6 & 5.0 & 3.4 & 3.0 & 4.3 & 4.0 & 1.0 & 1.0 & 1.3 & 1.0 \\
\hline
\end{tabular}

Notes

'DS is the firms' individual disclosure score on the 62 indicators. STRA is the firms' individual disclosure score on strategic issues (12 indicators).

COMP is the firms' disclosure score on competitive landscape and outlook (13 indicators). PROD is the firms' individual disclosure score on

production details (13 indicators). MARK is the firms' disclosure score on marketing strategy (13 indicators). HR is the firms' disclosure score on

Human capital (11 indicators).

${ }^{\mathrm{b}} \mathrm{n}$ is number of observations. 
TABLE 2

Pearson Correlations (p-values) $(n=152)$

\begin{tabular}{|c|c|c|c|c|c|c|c|}
\hline \multirow{3}{*}{$\mathrm{R}_{\mathrm{t}}$} & $\mathrm{R}_{\mathrm{t}}$ & $\mathrm{X}_{\mathrm{t}-1}$ & $X_{t}$ & $\mathrm{X} 3_{\mathrm{t}}$ & $\mathrm{R} 3_{\mathrm{t}}$ & $\mathrm{DS}_{\mathrm{t}}$ & MV \\
\hline & & 0.03096 & 0.30064 & 0.29248 & -0.05954 & 0.0509 & 0.11661 \\
\hline & & 0.705 & 0.0002 & 0.0003 & 0.4662 & 0.5335 & 0.1525 \\
\hline \multirow[t]{2}{*}{$X_{t-1}$} & & & 0.41351 & 0.20582 & 0.16332 & -0.04608 & -0.0047 \\
\hline & & & 0.00001 & 0.011 & 0.0444 & 0.5729 & 0.9541 \\
\hline \multirow[t]{2}{*}{$X_{t}$} & & & & 0.44252 & 0.22049 & -0.04299 & -0.04169 \\
\hline & & & & 0.00001 & 0.0063 & 0.599 & 0.6101 \\
\hline \multirow[t]{2}{*}{$\mathrm{X} 3_{\mathrm{t}}$} & & & & & 0.54521 & -0.14554 & -0.01594 \\
\hline & & & & & 0.00001 & 0.0736 & 0.8454 \\
\hline \multirow[t]{2}{*}{$\mathrm{R} 3_{\mathrm{t}}$} & & & & & & -0.10214 & -0.14433 \\
\hline & & & & & & 0.2105 & 0.0761 \\
\hline \multirow[t]{2}{*}{$\mathrm{DS}_{\mathrm{t}}$} & & & & & & & 0.2299 \\
\hline & & & & & & & 0.0044 \\
\hline
\end{tabular}

Current returns (Rt) for year $\mathrm{t}$ are the buy and hold returns for the 12 month period starting four months after year t-1 fiscal year end. Current earnings (Xt) for the year $t$ is ordinary income, scaled by market value at fiscal year end Future earnings (X3t) is the sum of ordinary income for the three years following the current year scaled by market value at fiscal year end. Future returns (R3t) are the buy and hold returns for the three year period following the current year. Market value is the market value of equity at the fiscal yearend. DS is the disclosure score. 
Table 3

Regression on current returns on current and aggregated future earnings and interactions with disclosure $(\mathrm{n}=152)$

\begin{tabular}{|c|c|c|}
\hline Independent variables & Model 1 & Model 2 \\
\hline \multirow[t]{2}{*}{ Intercept } & -0.04386 & -0.08566 \\
\hline & 0.2486 & 0.3903 \\
\hline \multirow[t]{2}{*}{$X_{t-1}$} & -0.17377 & -0.83604 \\
\hline & 0.2914 & 0.2574 \\
\hline \multirow[t]{2}{*}{$\mathrm{X}_{\mathrm{t}}$} & 0.47948 & 0.77901 \\
\hline & 0.008 & 0.1506 \\
\hline \multirow[t]{2}{*}{$\mathrm{X} 3_{\mathrm{t}}$} & 0.26517 & 0.40145 \\
\hline & 0.0002 & 0.0512 \\
\hline \multirow[t]{2}{*}{$\mathrm{R} 3_{\mathrm{t}}$} & -0.22418 & -0.15571 \\
\hline & 0.0011 & 0.3119 \\
\hline \multirow[t]{2}{*}{ DS } & & 0.00418 \\
\hline & & 0.5511 \\
\hline \multirow[t]{2}{*}{$\mathrm{DS}_{\mathrm{t}} * \mathrm{X}_{\mathrm{t}-1}$} & & 0.03602 \\
\hline & & 0.4449 \\
\hline \multirow[t]{2}{*}{$\mathrm{DS}_{\mathrm{t}} * \mathrm{X}_{\mathrm{t}}$} & & -0.01749 \\
\hline & & 0.5785 \\
\hline \multirow[t]{2}{*}{$\mathrm{DS}_{\mathrm{t}} * \mathrm{X} 3_{\mathrm{t}}$} & & -0.01039 \\
\hline & & 0.4665 \\
\hline \multirow[t]{2}{*}{$\mathrm{DS}_{\mathrm{t}} * \mathrm{R} 3_{\mathrm{t}}$} & & -0.00411 \\
\hline & & 0.6877 \\
\hline
\end{tabular}

Adjusted $\mathrm{R}^{2}$

0.1773

0.1646

Current returns (Rt) for year t are the buy and hold returns for the 12 month period starting four months after year t- 1 fiscal year end. Current earnings $(\mathrm{Xt})$ for the year $\mathrm{t}$ is ordinary income, scaled by market value at fiscal year end future earnings (X3t) is the sum of ordinary income for the three years following the current year scaled by market value at fiscal year end. Future returns (R3t) are the buy and hold returns for the three year period following the current year. DS is the disclosure score. 
TABLE 4

Regression of Current Returns on Current and future earnings and returns and interactions with disclosure ( $\mathrm{n}=152)$

\begin{tabular}{|c|c|c|c|c|c|c|c|c|c|c|c|c|c|c|c|c|c|c|}
\hline Intercept & $\mathrm{X}_{\mathrm{t}-1}$ & $X_{t}$ & $X_{t+1}$ & $\mathrm{X}_{\mathrm{t}+2}$ & $X_{t+3}$ & DS & $\mathrm{DS}_{\mathrm{t}}^{*} \mathrm{X}_{\mathrm{t}-1}$ & $\mathrm{DS}_{\mathrm{t}}{ }^{*} \mathrm{X}_{\mathrm{t}}$ & $\mathrm{DS}_{\mathrm{t}}^{*} \mathrm{X}_{\mathrm{t}+1}$ & $\mathrm{DS}_{\mathrm{t}} * \mathrm{X}_{\mathrm{t}+2}$ & $\mathrm{DS}_{\mathrm{t}}^{*} \mathrm{X}_{\mathrm{t}+3}$ & $\mathrm{R}_{1}$ & $\mathrm{R}_{2}$ & $\mathrm{R}_{3}$ & $\mathrm{DS}_{\mathrm{t}}^{*} \mathrm{R}_{\mathrm{t}+1}$ & $\mathrm{DS}_{\mathrm{t}} * \mathrm{R}_{\mathrm{t}+2}$ & $\mathrm{DS}_{\mathrm{t}} * \mathrm{R}_{\mathrm{t}+3}$ & $\begin{array}{c}\text { Adjusted } \\
\mathrm{R}^{2}\end{array}$ \\
\hline $0.14614^{-}$ & 0.23967 & 0.83969 & 1.09832 & -0.74287 & 0.56698 & 0.00817 & -0.00267 & -0.02295 & -0.06487 & 0.07536 & -0.0307 & 0.09833 & -0.19915 & 0.09704 & -0.00936 & -0.00497 & -0.01536 & 0.1721 \\
\hline 0.1229 & 0.5539 & 0.1592 & 0.0701 & 0.2221 & 0.212 & 0.247 & 0.9388 & 0.495 & 0.545 & 0.0771 & 0.3745 & 0.6234 & 0.3263 & 0.6031 & 0.4502 & 0.7396 & 0.244 & \\
\hline
\end{tabular}

Current returns (Rt) for year $t$ are the buy and hold returns for the 12 month period starting four months after year. $t-1$ fiscal year end. Current earnings (Xt) for the year $t$ is ordinary income, scaled by market

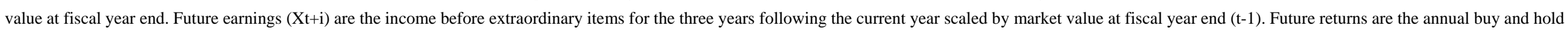
returns for the three year period following the current year. DS is the disclosure score. 
TABLE 5

Regressions of current returns on aggregated current and future earnings and interactions with disclosure and controls for the determinants of earnings response coefficients and the sign of the dependent variable $(n=152)$

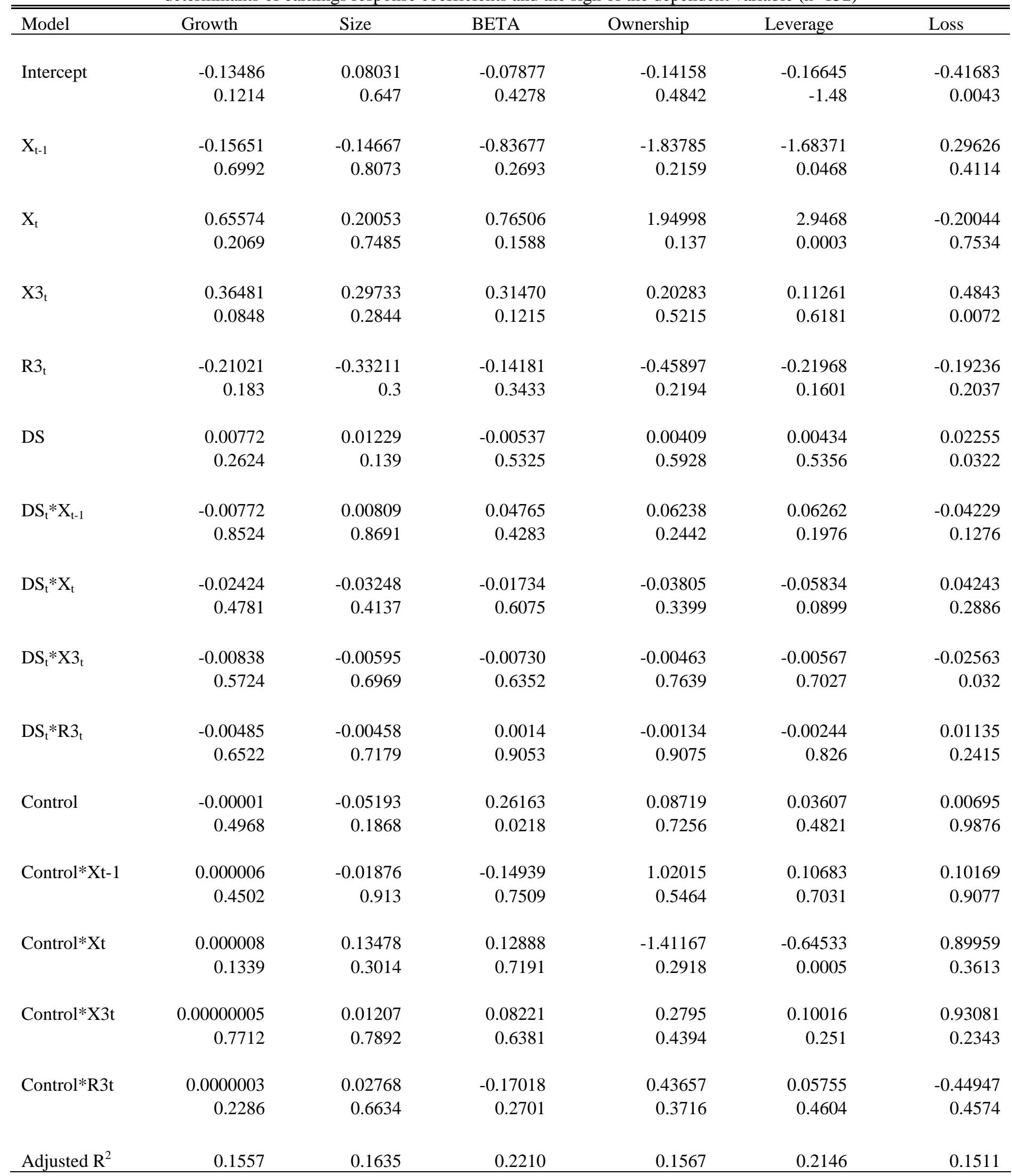


Current returns (Rt) for year $t$ are the buy and hold returns for the 12 month period starting four months after year $\mathrm{t}-1$ fiscal year end. Current earnings (Xt) for the year $\mathrm{t}$ is ordinary income, scaled by market value at fiscal year end Future earnings (X3t) is the sum of ordinary income for the three years following the current year scaled by market value at fiscal year end. Future returns (R3t) are the buy and hold returns for the three year period following the current year. DS is the disclosure score. Growth is defined as the percentage growth in the firm's assets from year t- 1 to year $t$ Size is the natural log of market value of equity at the end of the firm's fiscal year t-1 Beta is calculated using monthly returns from datastream over year $\mathrm{t}-\mathrm{t}+5$. Ownership concentration is measured as shares held by blockholders including officers, directors (and their families), trusts, pension/benefit plans, and shares held by other firms or individuals that hold more than $5 \%$. Leverage is calculated as liability/equity for the fiscal year. Loss is an indicator variable that is set equal to 1 when ordinary income is negative and zero otherwise. 
TABLE 6

High vs. Low regression $(n=70)$

\begin{tabular}{|c|c|c|c|c|c|c|c|}
\hline Model & & MV & OWN & LEVERAGE & BETA & GROWTH & LOSS \\
\hline Intercept & $\begin{array}{r}-0.44055 \\
0.0063\end{array}$ & $\begin{array}{r}-0.3205 \\
0.4396\end{array}$ & $\begin{array}{r}-0.4188 \\
0.2922\end{array}$ & $\begin{array}{r}-0.7316 \\
0.0001\end{array}$ & $\begin{array}{r}-0.45520 \\
0.0153\end{array}$ & $\begin{array}{r}-0.44767 \\
0.0075\end{array}$ & $\begin{array}{r}-0.46569 \\
0.0017\end{array}$ \\
\hline$X_{t-1}$ & $\begin{array}{r}2.92749 \\
0.0376\end{array}$ & $\begin{array}{l}1.8064 \\
0.4229\end{array}$ & $\begin{array}{r}3.70773 \\
0.2218\end{array}$ & $\begin{array}{r}2.81031 \\
0.0425\end{array}$ & $\begin{array}{r}0.87131 \\
0.5996\end{array}$ & $\begin{array}{r}3.07106 \\
0.0373\end{array}$ & $\begin{array}{r}3.08546 \\
0.0149\end{array}$ \\
\hline$X_{t}$ & $\begin{array}{r}-0.06087 \\
0.9511\end{array}$ & $\begin{array}{r}0.02425 \\
0.9869\end{array}$ & $\begin{array}{r}-2.05133 \\
0.2972\end{array}$ & $\begin{array}{r}3.17887 \\
0.0108\end{array}$ & $\begin{array}{r}1.91779 \\
0.070\end{array}$ & $\begin{array}{r}-0.10683 \\
0.9167\end{array}$ & $\begin{array}{r}-0.01539 \\
0.9884\end{array}$ \\
\hline $\mathrm{X} 3_{\mathrm{t}}$ & $\begin{array}{r}0.74153 \\
0.006\end{array}$ & $\begin{array}{r}0.17376 \\
0.7893\end{array}$ & $\begin{array}{l}1.8818 \\
0.0982\end{array}$ & $\begin{array}{r}0.36194 \\
0.2493\end{array}$ & $\begin{array}{r}0.66418 \\
0.0799\end{array}$ & $\begin{array}{l}0.7057 \\
0.0123\end{array}$ & $\begin{array}{r}0.74981 \\
0.003\end{array}$ \\
\hline DS & $\begin{array}{r}0.35825 \\
0.0515\end{array}$ & $\begin{array}{r}0.52351 \\
0.0565\end{array}$ & $\begin{array}{r}0.34875 \\
0.1107\end{array}$ & $\begin{array}{r}0.25134 \\
0.1485\end{array}$ & $\begin{array}{r}0.00407 \\
0.7398\end{array}$ & $\begin{array}{r}0.41707 \\
0.0511\end{array}$ & $\begin{array}{r}0.31494 \\
0.0576\end{array}$ \\
\hline DS*Xt-1 & $\begin{array}{r}-2.82897 \\
0.0541\end{array}$ & $\begin{array}{r}-4.26185 \\
0.0374\end{array}$ & $\begin{array}{r}-3.7603 \\
0.0736\end{array}$ & $\begin{array}{r}-1.67888 \\
0.2338\end{array}$ & $\begin{array}{r}0.01341 \\
0.8842\end{array}$ & $\begin{array}{r}-3.75489 \\
0.0408\end{array}$ & $\begin{array}{r}-3.78196 \\
0.0076\end{array}$ \\
\hline DS* $X_{t}$ & $\begin{array}{r}0.77475 \\
0.4529\end{array}$ & $\begin{array}{r}0.91659 \\
0.4224\end{array}$ & $\begin{array}{r}1.33919 \\
0.2545\end{array}$ & $\begin{array}{r}0.09975 \\
0.9197\end{array}$ & $\begin{array}{r}-0.07279 \\
0.1566\end{array}$ & $\begin{array}{r}0.58738 \\
0.6029\end{array}$ & $\begin{array}{r}1.60286 \\
0.1351\end{array}$ \\
\hline $\mathrm{DS} * \mathrm{X} 3_{\mathrm{t}}$ & $\begin{array}{r}-0.60431 \\
0.0649\end{array}$ & $\begin{array}{r}-0.94664 \\
0.0406\end{array}$ & $\begin{array}{r}-0.8426 \\
0.0436\end{array}$ & $\begin{array}{r}-0.40202 \\
0.2359\end{array}$ & $\begin{array}{r}-0.000512 \\
0.9797\end{array}$ & $\begin{array}{r}-0.64488 \\
0.0825\end{array}$ & $\begin{array}{r}-0.79585 \\
0.01111\end{array}$ \\
\hline $\mathrm{R} 3_{\mathrm{t}}$ & $\begin{array}{r}-0.44759 \\
0.0086\end{array}$ & $\begin{array}{l}0.2921 \\
0.6202\end{array}$ & $\begin{array}{r}-0.89475 \\
0.0483\end{array}$ & $\begin{array}{r}-0.4171 \\
0.0178\end{array}$ & $\begin{array}{r}-0, .31018 \\
0.1224\end{array}$ & $\begin{array}{r}-0.43665 \\
0.0135\end{array}$ & $\begin{array}{r}-0.43759 \\
0.004\end{array}$ \\
\hline $\mathrm{DS} * \mathrm{R} 3_{\mathrm{t}}$ & $\begin{array}{r}0.19127 \\
0.3624\end{array}$ & $\begin{array}{r}0.54441 \\
0.155\end{array}$ & $\begin{array}{r}0.3502 \\
0.14\end{array}$ & $\begin{array}{r}0.18785 \\
0.3898\end{array}$ & $\begin{array}{r}0.00824 \\
0.5894\end{array}$ & $\begin{array}{r}0.18133 \\
0.4616\end{array}$ & $\begin{array}{r}0.35491 \\
0.065\end{array}$ \\
\hline Control & & $\begin{array}{r}-0.0349 \\
0.6725\end{array}$ & $\begin{array}{r}0.01865 \\
0.9722\end{array}$ & $\begin{array}{r}0.15846 \\
0.0311\end{array}$ & $\begin{array}{r}0.35635 \\
0.0573\end{array}$ & $\begin{array}{l}-1 E-09 \\
0.6837\end{array}$ & $\begin{array}{r}-0.43967 \\
0.1143\end{array}$ \\
\hline Control*Xt-1 & & $\begin{array}{r}0.32919 \\
0.4158\end{array}$ & $\begin{array}{r}-1.30477 \\
0.7392\end{array}$ & $\begin{array}{r}-0.39855 \\
0.3537\end{array}$ & $\begin{array}{r}-0.79727 \\
0.2864\end{array}$ & $\begin{array}{r}0.00000001 \\
0.4237\end{array}$ & $\begin{array}{r}1.21102 \\
0.1584\end{array}$ \\
\hline Control*Xt & & $\begin{array}{r}-0.03066 \\
0.8818\end{array}$ & $\begin{array}{r}2.65063 \\
0.2194\end{array}$ & $\begin{array}{r}-1.18529 \\
0.0004\end{array}$ & $\begin{array}{r}0.02838 \\
0.9503\end{array}$ & $\begin{array}{r}0.000000006 \\
0.4733\end{array}$ & $\begin{array}{r}-1.74164 \\
0.075\end{array}$ \\
\hline Control*X3t & & $\begin{array}{r}0.12003 \\
0.356\end{array}$ & $\begin{array}{r}-0.66253 \\
0.4706\end{array}$ & $\begin{array}{r}0.10978 \\
0.4113\end{array}$ & $\begin{array}{r}-0.66202 \\
0.1301\end{array}$ & $\begin{array}{r}0.000000003 \\
0.4822\end{array}$ & $\begin{array}{r}1.62099 \\
0.005\end{array}$ \\
\hline Control*R3t & & $\begin{array}{r}-0.15422 \\
0.2167\end{array}$ & $\begin{array}{r}0.67619 \\
0.2995\end{array}$ & $\begin{array}{r}0.04273 \\
0.6369\end{array}$ & $\begin{array}{r}-0.19886 \\
0.3993\end{array}$ & $\begin{array}{r}0.000000001 \\
0.849\end{array}$ & $\begin{array}{r}-1.45212 \\
0.0043\end{array}$ \\
\hline Adjusted $\mathrm{R}^{2}$ & 0.2196 & 0.1996 & 0.1978 & 0.3451 & 0.2597 & 0.1779 & 0.3969 \\
\hline
\end{tabular}

Current returns (Rt) for year t are the buy and hold returns for the 12 month period starting four months after year 
t-1 fiscal year end. Current earnings (Xt) for the year t is ordinary income, scaled by market value at fiscal year end Future earnings (X3t) is the sum of ordinary income for the three years following the current year scaled by market value at fiscal year end. Future returns (R3t) are the buy and hold returns for the three year period following the current year. DS is the disclosure score. Growth is defined as the percentage growth in the firm's assets from year t-1 to year $t$ Size is the natural log of market value of equity at the end of the firm's fiscal year t-1 Beta is calculated using monthly returns from datastream over year $\mathrm{t}-\mathrm{t}+5$. Ownership concentration is measured as shares held by blockholders including officers, directors (and their families), trusts, pension/benefit plans, and shares held by other firms or individuals that hold more than 5\%. Leverage is calculated as liability/equity for the fiscal year Loss is an indicator variable that is set equal to 1 when ordinary income is negative and zero otherwise. 